\title{
$\mathrm{NiAl}$ におけるボロンの固溶限と固溶強化
}

\author{
譚毅什篠田哲守** \\ 三島良直*** 鈴木朝夫**** \\ *大連理工大學材料工程系 \\ **侏日立製作所日立研究所 \\ ***東京工業大学精密工学研究所 \\ ****東京工業大学工学部金属工学科
}

J. Japan Inst. Metals, Vol. 57, No. 3 (1993), pp. 356-361

\section{Solid Solubility and Solid Solution Hardening of Boron in NiAl}

\author{
Yi Tan*, Tetsumori Shinoda**, \\ Yoshinao Mishima*** and Tomoo Suzuki**** \\ *Department of Materials Engineering, Dalian University of Technology, Dalian, China \\ ${ }^{* *}$ Hitachi Research Laboratory, Hitachi Ltd., Hitachi \\ ***Precision and Intelligence Laboratory, Tokyo Institute of Technology, Nagatuta, \\ Midori-ku, Yokohama 227, Japan \\ ****Department of Metallurgical Engineering, Tokyo Institute of Technology, \\ Ookayama, Meguro-ku, Tokyo 152, Japan
}

\begin{abstract}
With boron-doped NiAl alloys, the solubility of boron, the composition and structure of the precipitated boride and the change in fracture mode due to boron addition have been studied. The solubility of boron is very small on the Ni-rich side of the alloys with a slight increase in its magnitude with deviation from the stoichiometric composition of the alloys, while the solubility of boron on the Al-rich side can be neglected. The structure of the precipitated boride on the Ni-rich side of the $\mathrm{NiAl}\left(45\right.$ at\% Al) alloy is a $\mathrm{Cr}_{23} \mathrm{C}_{6}$ type compound, where composition is $\mathrm{Ni}_{60} \mathrm{Al}_{10} \mathrm{~B}_{30}$ and the lattice parameter of which is $1.0542 \mathrm{~nm}$.

The fracture mode for the alloys changes from the intergranular to the transgranular type of fracture as an increase in boron concentration for both sides of Ni- and Al-rich compositions. However, the critical concentration of boron to the mode change in fracture mode is 0.003 mass \% on the Ni-rich side, whereas it is 0.02 mass\% on the Alrich side.
\end{abstract}

(Received October 19, 1992)

Keywords: NiAl with boron, nickel-aluminum-boron phase diagram, solid solution hardening in $\mathrm{NiAl}, \mathrm{Cr}_{23} \mathrm{C}_{6}$ type compound $\mathrm{Ni}_{20} \mathrm{Al}_{3} \mathrm{~B}_{6}$, fracture mode of $\mathrm{NiAl}$

I. 緒言

前報に和いて，化学量論組成からのずれによる NiAlの欠陥 強化，ならびに強化に拉よぼす 0.05 mass\%のボロソ添加の影 響について報告した(1)。それによれば，Ni過剩側合金にボ口 ンを添加したとき，化学量論組成からずれる㭱ど格子定数む硬 さも大となるが，Al過剩側合金ではボロンを添加してる，格 子定数にも硬さにも何らの変化が認められないことを報告し た.このことから, $\mathrm{Ni}$ 過㮃側合金では添加したボロンの一部 は固溶し，残りのボロンはボライドの形で粒内と粒界に存在す ること, $\mathrm{Al}$ 過剰側合金にボロンは全く固溶せず，ボライドも

†現在 : 東京工業大学
存在しないことを明らかにした。しかし，Ni 過㮃側合金に対 するボロンの固溶量, 析出したボライドの組成, 結晶構造, $\mathrm{Al}$ 過剩側合金に叔けるボロンの存在状態，また破壊モードに 执よぼす影響などの多くの問題が残されている.

Chabon らは, Ni 過剩側の $\mathrm{NiAl} \beta$ 相は 3 元組成のボライド $\pi$ 相放るいは $\tau$ 相と平衡し, $\mathrm{Al}$ 過剩側の $\mathrm{NiAl} \beta$ 相は単体のボ ロン，(B)相と平衡する Ni-Al-B 3 元状態図を棈成している(2). な抏ここの状態図については前報の Fig. 10 を参照していたた きたい(1).しかし，この状態図はボロンの固溶限化ついての議 論を行ら汪ど精細なものではない. George は化学量諭組成の $\mathrm{NiAl}$ に微量ボロンを添加した際の室温の機械的性質を調べ, 破壞モードはボロン添加により，粒界破壊から粒内破壊へ变化 することを報告しているが(3)，化学量論組成の両側でのボロン 添加による破壊モードの变化については不明のままである。 
$\mathrm{Ni}_{3} \mathrm{Al}$ 合金の $\mathrm{Al}$ 過剰側では延性の改善効果が生じない理由と して，ボロンが粒界に偏析し難いためとの説もある(4). $\mathrm{Al}$ 過 剩側の NiAl ではボロンは粒界に偏析しているであるうことを 前報で述べた(1).したがって，このことは $\mathrm{Al}$ 過剩側 $\mathrm{NiAl} の$ 破髙モードを变化させる可能性が大きいことを示している。

本研究は, NiAl に和けるボロンの固溶限, ならびに析出し ている化合物相の組成, 結晶構造について, 零たボロンを添加 することによる合金の破壊モードの变化について，化学量論組 成をはさむ 3 種の NiAlを用いてボロン添加のレベルを变兄て 調べたものである。

\section{II. 実 験 方 法}

$\mathrm{NiAl}(45 \mathrm{at} \% \mathrm{Al}), \mathrm{NiAl}(52.5 \mathrm{at} \% \mathrm{Al}) ，$ 括よび $\mathrm{NiAl}(49.5$ at $\% \mathrm{Al}$ ) 3 種類の合金を選んで，ボロンの添加量を変化させ た 3 元合金を作成した。

実験に供したボロン添加，無添加 NiAl は純度 99.9 mass\% の電解ニッケル，99.99 mass\%のアルミニウムを原料として， 非消耗タングステン電極アーク溶解によりアルゴン雾囲気中に て溶解した、ボロンの添加は 15 mass\%ボロンを含むNi-B 母

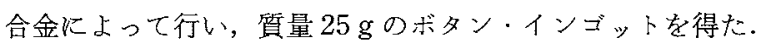
得られたインゴットを石英管に真空封入し，1373 K-24hの均 質化熱処理を行ったのら空冷した。

格子定数の測定は粉末法に上り測定した。均質化熱処理した インゴットの一部をハンマーで粉砕し，乳鉢で擦り潰し粉末と した．粉未化の過程中に導入される変形ひずみを取るため，さ らに真空中で $1123 \mathrm{~K}-1 \mathrm{~h}$ の熱処理を行ったのち空冷した．格 子定数測定は，この粉末試料にエタノールを加觉がラスホルダ 一上に $15 \mathrm{~mm} \times 20 \mathrm{~mm} \times 0.5 \mathrm{~mm}$ の板状火充填し, 理学電機 製 X 線回折装置 RAD- IIA 老用いて，電圧 $40 \mathrm{kV}$ ，電流 20 $\mathrm{mA}$ で, 主として Cu-K $\alpha$ 線による (310) 回折線の回折角に上 り行った。

硬さ測定はビッカース微小硬さ計を用い, 荷重 $2.94 \mathrm{~N}(300$ gf)，時間 $30 \mathrm{~s}$ の条件下で 5 点の測定を行い，平均值を用い た。析出物や粒界の硬さは荷重を $0.49 \mathrm{~N}(50 \mathrm{gf})$ と小さくした 条件で測定した，硬さのばらつきは平均値の $2 \%$ 程度である。 ボロン添加合金の析出物の組成は電子線マイクロ・アナライザ 一により測定した。また，析出物の結晶構造解析は，95\%酢 酸 $+5 \%$ 過塩素酸涅合溶液を使い，電压 $0.2 \mathrm{mV}$ で電解抽出 L て得た粉末により行った。

ボロン添加に上る破壊モードの変化を知るために破面を観察 した、インゴットから適当な大きさの試駼片を切り出し, 液体 窒素で冷やしたのち，ハンマーで破断した。破面観察は日本電 子製の JSN-T200S 型の走査型電子影徽鏡を用い，25 kV で行 $\curvearrowright た$.

\section{III. 実 験 結 果}

\section{1. 格子定数, ならび硬さのボロン濃度依存性}

Fig. 1 は NiAl の格子定数とボロン濃度の関係を示したもの である. Ni 過剩側の NiAl (45 at\% $\mathrm{Al}$ ) 合金の格子定数はボロン の濃度の增加炕したがって增加し，ボロンの添加量が 0.013

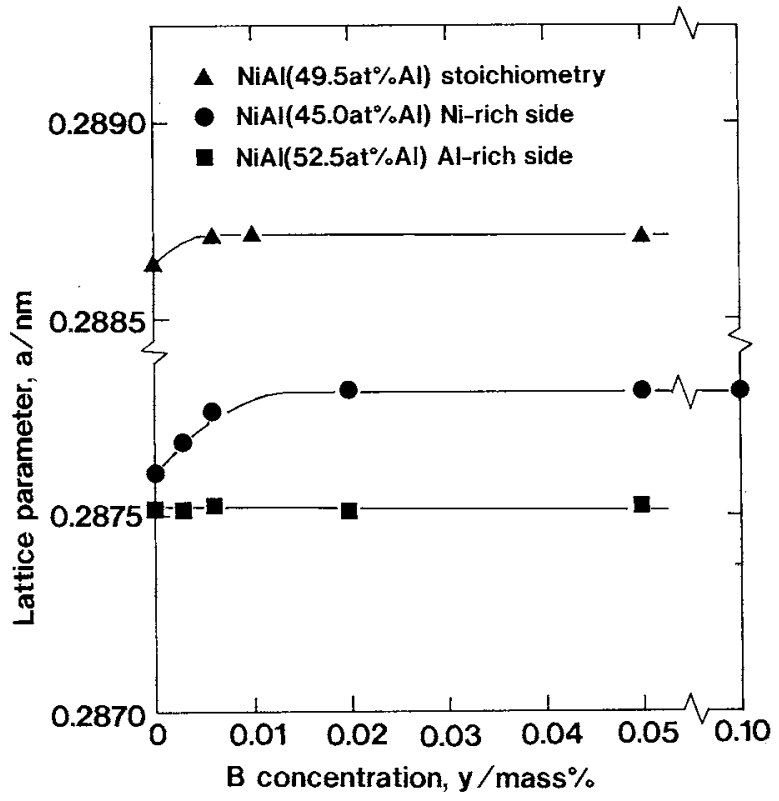

Fig. 1 Relation between lattice parameter and boron content for $\mathrm{NiAl}$ alloys.

mass\%以上になると，格子定数は一定值に達する。この濃度 は NiAl(45at\%Al)火おけるボロンの固溶限と見て良い，化学 量論組成近傍わずかに Ni 過剰側の $\mathrm{NiAl}(49.5 \mathrm{at} \% \mathrm{AI})$ では, ボロンの添加により格子定数は増加し， $\mathrm{NiAl}(45 \mathrm{at} \% \mathrm{Al})$ と同 じ䫏向を示すが，一定值に達するボロン濃度は低下している。 すなうち，ボロンの固溶限は小さくなっている。一方，Al過 剰側の $\mathrm{NiAl}(52.5$ at \% Al)の格子定数はボロン添加によって全 く変化していない.

Fig. 2 は硬さのボロン濃度低存性を示したものである. Ni

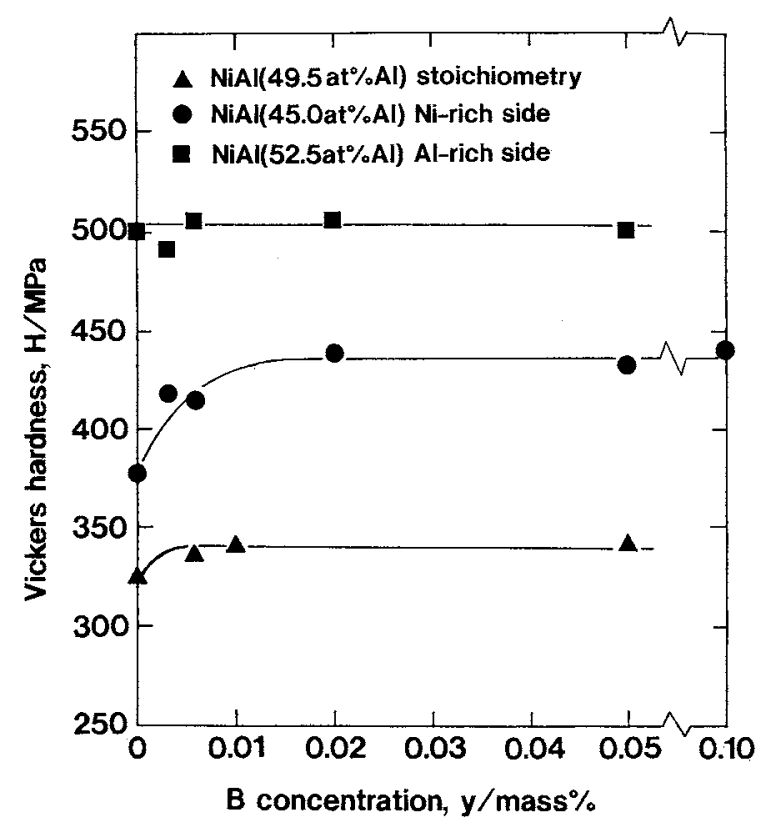

Fig. 2 Relation between Vickers hardness and boron content for NiAl alloys. 
過剩側の $\mathrm{NiAl}(45$ at\%Al)の硬さはボロン濃度の堌加にしたが って増加するが，ボロンの添加量が 0.013 mass\%以上になる と硬さは一定値に達する。この変化はボロン添加による慗子定 数の変化とよく対応している．化学量論組成近傍の $\mathrm{Ni}$ 過刮側 の $\mathrm{NiAl}(49.5$ at \%)では，格子定数が一定值に達するボロン濃 度が低下しているが，硬さの変化もこれに対応している．A1 過剩側の $\mathrm{NiAl}(52.5$ at \% Al) では，ボロン添加による格子定数 の増加舟硬さの増加名認められない，以上の結果からボロンは $\mathrm{NiAl}$ K侵入型に固溶し，これに対応して硬さが上昇すると結 論できる。

\section{2. ホホロン添加 NiAl の粒界硬さ}

ボロンを添加した合金の均質化熱処理後の組織観察により， $\mathrm{Ni}$ 過剰側 NiAl では固溶限濃度以上のボロンを添加すれば，粒 界にボライドと考光られる析出物が認められるようになる。ボ ロンの添加量がさらに增光ると粒内にもしだいに丸い析出物が 見觉るよらになる。一方， $\mathrm{Al}$ 過剩側の NiAlでは，0.05 mass\%以下のボロン添加範囲では粒界と粒内いずれにも析出 物は認められない。また，ボロン添加した $\mathrm{Ni}$ 過剰側 $\mathrm{NiAl}$, 例 亲ば 0.05 mass\%ボロンを添加した合金では，化学量論組成か ら $\mathrm{Ni}$ 過剩側にずれる汪ど析出物の量が多くなる.これらのこ とはすでに前報で報告したとおりである(1)。

Fig. 3 には永ロン無添加 NiAl と0.05 mass\% ポロン添加

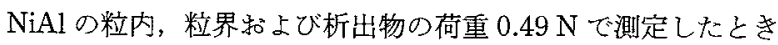
の硬さを示す．図中にはFig. 1 と Fig. 2 に示した材料の他に 前報(1)の試料を用いて測定したデータも加えてある．粒内の硬 さについて芫れば，化学量論組成からのずれ，特よびボロン添 加による変化は基本的に愔前報に示したFig. 4 の傾向と一致 している。ボロン無添加合金では， $\mathrm{Ni}$ 過剩側であっても， $\mathrm{Al}$ 過剩側であっても, 粒界之粒内の硬さに差は認められない。こ の結果はWestbrookとWoodの結果と一致しない。すなる ら，彼らの結果は Ni 過剩側では粒界と粒内の硬さが同じであ るが， $\mathrm{Al}$ 過剩側で粒界の硬さが粒内のそれより高くなってい る. 彼らはその原因を酸素や空素などの不純物が粒界に偏析し

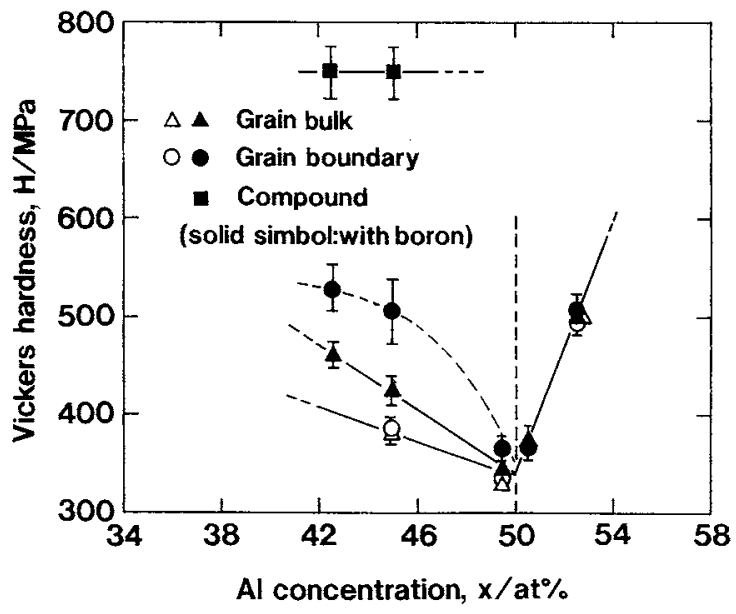

Fig. 3 Bulk and grain boundary hardnesses of $\mathrm{NiAl}$ and 0.05 mass \% boron-doped NiAl at room temperature as a function of composition.
ているためと考察している(5). 溶解法や原料の純度の羑がこの 原因であると考克られる。

つぎに 0.05 mass\%のボロンを添加した NiAl Kついて述べ る. $\mathrm{Ni}$ 過剩側 $\mathrm{NiAl}$ の粒界の硬さは粒内上り高く，かつ化学量 論組成からのずれが大となるほどこの差が大きくなる，一方， $\mathrm{Al}$ 過剩側 NiAl では粒界と粒内の硬さの差は認められない。 挔，粒内の硬さは粒内析出物を避けて測定したものである。こ の変化はボロン添加による組織の美から理解できる。析出物は $\mathrm{Ni}$ 過剩側だけに存在し，かつ析出量は化学量諭組成からずれ る注ど多くなることはさきに述べたと扣りである。交た图に示 すように粒内执よび粒界に存在する析出物の硬さには全く差が

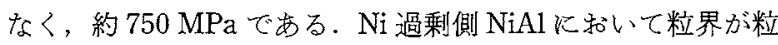
内より硬くなるのは粒界に存在する析出物のためであると結諭 できる.

\section{3. 析出物の組成と結晶構造}

Table 1は電子線マイクロ・アナライザーによって得た 0.05 mass\% ボロンを添加した NiAl (45 at\% Al)の粒界々粒内 の析出物の組成分析結果である。粒界之粒内の析出物の組成炕 有意差はなく，同一のるのである。電解抽出した析出物の X 線回折結果を Fig. 4 亿示す. 図中には $\mathrm{Cr}_{23} \mathrm{C}_{6}$ の回折結果を一 緒に示してある(6)。以上の結果から，NiAl(45 at\% $\mathrm{Al}$ ) 飞 0.05 mass\%ボロンを添加した合金に析出しているものは $\mathrm{Cr}_{23} \mathrm{C}_{6}$ 型 の結晶構造をつ 3 元組成のボライド $\mathrm{Ni}_{20} \mathrm{Al}_{3} \mathrm{~B}_{6} \tau$ 相であり， 格子定数は $1.0542 \mathrm{~nm}$ である. $\mathrm{Cr}_{23} \mathrm{C}_{6}$ の最も低角側の回折は (311)反射であるのに対して，この $て$ 相の最も低角側の回折は (220)反射である.こ和は Stadelmaierらの結果と一致してい る.彼らの結果には，回折角が示されていないが，(220)の反 射を認めている(7)。このような例は 3 元組成化合物に上く見 られる. $\mathrm{M}_{23} \mathrm{C}_{6}$ 型の結晶構造をるつ $\mathrm{Co}_{21} \mathrm{~W}_{2} \mathrm{~B}_{6}$ の反射指数は (200)からであるが(8)， $\mathrm{Co}_{21} \mathrm{Ce}_{2} \mathrm{~B}_{6}$ のそれは(400)からであ る(9)、また，このボライドの格子定数 $1.0542 \mathrm{~nm}$ は $\mathrm{Cr}_{23} \mathrm{C}_{6}$ の $1.062 \mathrm{~nm}$ 上り小さい(6).

なお， $\mathrm{Al}$ 過剩側 NiAl では電解抽出によって試験を行らほど の残査を得ることはでさなかった。

\section{4. ボロン添加 NiAl の破面観察}

Fig. 5 は化学量諭組成の峏側のボロン添加, 無添加合金の 典型的な破面組織を示したものである。ボロン無添加材では， $\mathrm{Ni}$ 過剩側, $\mathrm{Al}$ 過剩側のいずれに叔いて子粒界破壊を呈する。 このことは既往の結果と一致している(3)(10).ボロン添加材で は，化学量論組成の両側のいずれにおいても破壊モードは粒界 破壊から粒内破壊へ変わる，ただし，破壊モードが変化するボ ロン濃度が異なっている．Table 2 は破壊モードとボロン濃度

Table 1 Compositions of the borides in grain bulk and at grain boundary for $\mathrm{NiAl}$ ( 45 at $\% \mathrm{Al}$ ) with 0.05 mass $\%$ boron obtained by EPMA, (at\%).

\begin{tabular}{l|c|c|c}
\hline \hline & $\mathrm{Al}$ & $\mathrm{Ni}$ & $\mathrm{B}$ \\
\hline Boride in grain bulk & 10.1 & 57.0 & 32.8 \\
\hline Boride at grain boundary & 12.7 & 59.7 & 27.7 \\
\hline
\end{tabular}




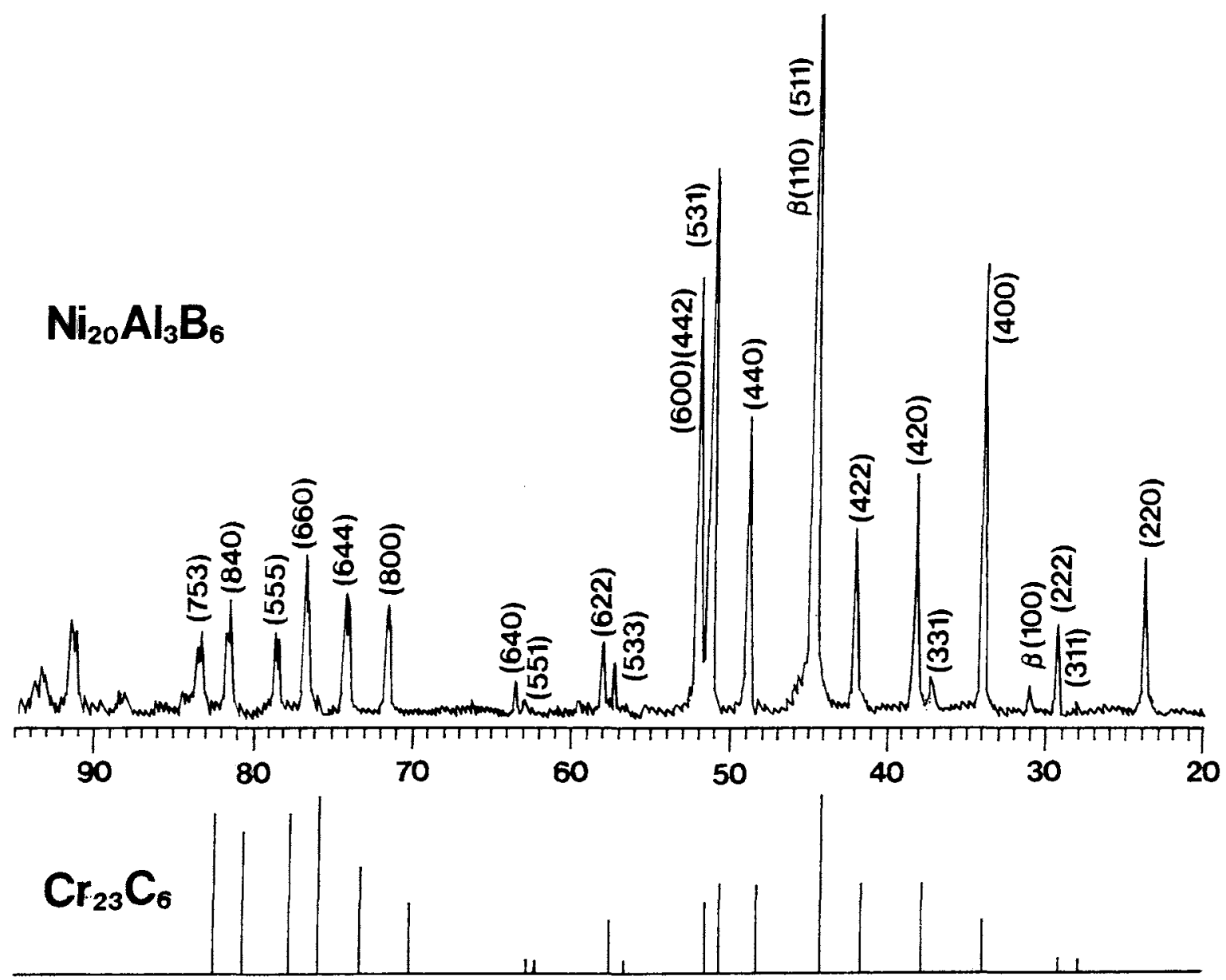

Fig. 4 X-ray patterns for the extracted boride in Ni-rich NiAl ( 45 at\% $\mathrm{Al}$ ) doped with 0.05 mass $\%$ boron and the filed data of $\mathrm{Cr}_{23} \mathrm{C}_{6}$ reported by Lux and Eberle ${ }^{(6)}$.

の関係を示したものである。Ni過唾側ではわずかのボロン添 加により破壊モードが変るるのに対して, $\mathrm{Al}$ 過剩側では粒内 破壊が生ずるボロンの濃度は $\mathrm{Ni}$ 過剩側のそれより高くなって いる.

\section{N. 考察}

\section{NiAl $\beta$ 相におけるボロンの固溶限}

Chabon らは $1273 \mathrm{~K} の \mathrm{Ni}-\mathrm{Al}-\mathrm{B} 3$ 元状態図を構成している. これとよれば, $\mathrm{Ni}$ 過剩側 $\mathrm{NiAl} \beta$ 相は $\tau$ 相や $\pi$ 相と名付けられ る3 元組成のボライドと共存し, $\mathrm{A} 1$ 過剩側 $\mathrm{NiAl} \beta$ 相はボロン 単体，(B) 相と共存している(2). Fig. 6 は Chabon の状態図と 本実験の結果から高とめた $1373 \mathrm{~K}$ に特る $\mathrm{NiAl} \boldsymbol{\beta}$ 相近傍の $\mathrm{Ni}-\mathrm{Al}-\mathrm{B} 3$ 元状態図である。この図では，2相領域 $(\beta+\tau)$ と $(\beta+\pi)$ の間の 3 相領域，执よび 2 相領域 $(\beta+\pi) と(\beta+(B)) \omega$ 間の 3 相領域は少し誇張して広げる状態で画いてある。な扣， 後述するように，本実験で $\pi$ 相の存在は確認していない。

格子間侵入型元素が bcc 型金属に固溶するとき，四面体位 置に入り，固溶量は一般少さい。 $\alpha$ - Fe や $\gamma$ - Fe 中以打ける $\mathrm{C} や \mathrm{~N}$ な゙の侵入型固溶体に括计る格子定数变化率は 0.07
$0.12 \mathrm{~nm} / \mathrm{at} \%$ 程度であるのK対して(11)，ボロン添加炕よる $\mathrm{NiAl}$ の格子定数の变化率は $0.31 \mathrm{~nm} / \mathrm{at} \%$ あ゙り，かなり大き い值を示している. $\mathrm{Al}$ 過剒側の NiAl では構造的な空孔が数多 く存在するため，ボロンが空孔に入れば，ボロンの固溶量がが なり大さくなると予想されるが，実際は㬰験結果が示すように そらではない，これは前報で述べたように，NiAlが電子化合 物と考えることにより理解できる(1)。細田による結合エネルギ 一の計算によれば， $\mathrm{Al}$ 過剩側の $\mathrm{NiAl} の \mathrm{Ni}$ サイトに, $\mathrm{Al}$ ある いはB を置換する場合比較して，構造的空孔を作る方が二 ネルギーが低くなる(12).

ここでNiAl に崖素を添加したときの挙動について言及して 扣く必要がある. Schusterらによれば, NiAl 亿炭素は和上そ 3 at\%固溶する。この場合の炭素は侵入型に固溶するのではな く，Ni 和よびAlサイトに置換する，したがって，炭素の固溶 により格子定数が低下する(13). Fleischer は固溶量が少ないが， $\mathrm{B} 2$ 構造の RuAl Kボロンを添加したとき，格子定数が小さく なることを報告している，RuAlに顿いてボロンは置換型に固 溶することを示している(14)。このよ5に電子化合物敒第 3 元 素が固溶する場合，溶質原子のサイズ因子だけでなく，溶質原 子と溶媒原子との原子間結合力や静電的効果がより重要な役割 


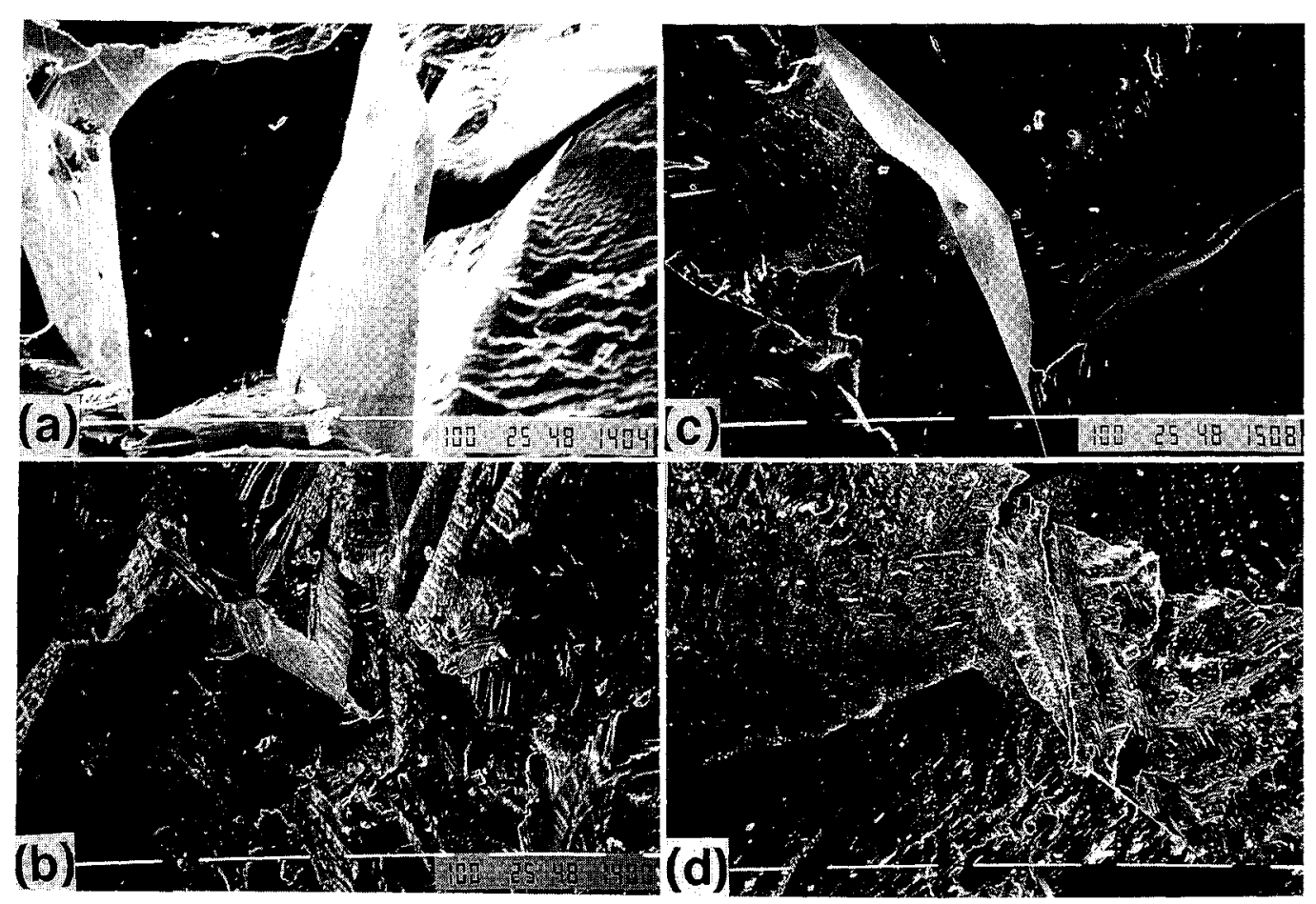

Fig. 5 Fracture modes of NiAl alloys. Length of a segment of white bars corresponds to $100 \mu \mathrm{m}$. (a) $\mathrm{NiAl}(45$ at $\% \mathrm{Al}),(\mathrm{b}) \mathrm{NiAl}(45$ at\% $\mathrm{Al})$ with 0.003 mass\% boron, (c) $\mathrm{NiAl}(52.5$ at\% $\mathrm{Al}$ ) with 0.006 mass\% boron, (d) $\mathrm{NiAl}(52.5$ at\% $\mathrm{Al})$ with 0.02 mass\% boron.

Table 2 Fracture mode of NiAl alloys.

\begin{tabular}{l|c|c|c|c|c|c}
\hline \hline \multirow{2}{*}{ Compound } & \multicolumn{6}{|c}{ Boron content (mass\%) } \\
\cline { 2 - 7 } & 0 & 0.003 & 0.006 & 0.01 & 0.02 & 0.05 \\
\hline $\mathrm{NiAl}(45$ at\% $\% \mathrm{Al})$ & $\times$ & 0 & 0 & - & 0 & 0 \\
$\mathrm{NiAl}(49.5$ at\% $\% \mathrm{Al})$ & $\times$ & - & 0 & 0 & - & 0 \\
$\mathrm{NiAl}(52.5$ at\% $\% \mathrm{Al})$ & $\times$ & $\times$ & $\times$ & - & 0 & 0 \\
\hline
\end{tabular}

$x$ : Fracture at grain boundary

$O$ : Fracture in grain bulk

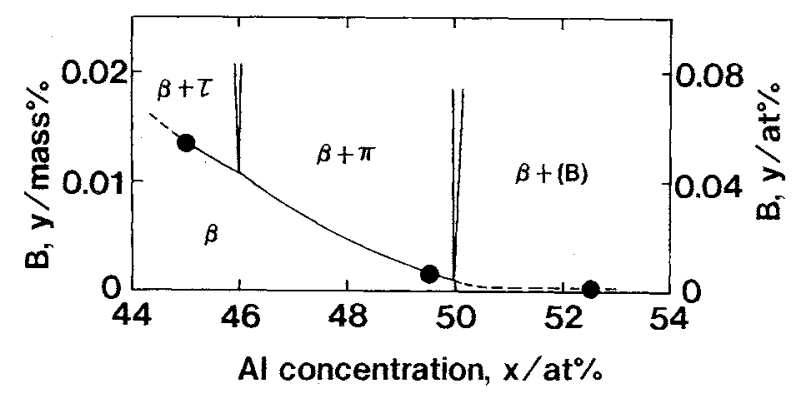

Fig. 6 Partial isothermal section of the Ni-Al-B ternary phase diagram at $1373 \mathrm{~K}$.

を果たしていることになる。

$\mathrm{Ni}$ 過剩側の $\mathrm{NiAl}(45$ at\% $\mathrm{Al}) \beta$ 相と共存する $\mathrm{M}_{23} \mathrm{C}_{6}$ 構造の ボライド $\tau$ 相の組成は $\mathrm{Ni}_{50} \mathrm{Al}_{10} \mathrm{~B}_{30}$ で势る. Stadelmaier と
Fraker は $1073 \mathrm{~K}$ の Ni-A1-B 3 元系状態図を調べ， $\tau$ 相は組成 が $\mathrm{Ni}_{68} \mathrm{Al}_{10} \mathrm{~B}_{22} \sim \mathrm{Ni}_{60} \mathrm{Al}_{10} \mathrm{~B}_{30}$ の範团であり，格子定数は 1.0484 1.0552 nm の範囲で変化すると報告している(7)(15)(16). これは Chabonの結果とも一致している. 彼らは $1373 \mathrm{~K}$ 亿括 汿る 3 元状態図の研究から，この化合物が $\mathrm{Al}$ が10 at\%と一定 であり， $\mathrm{Cr}_{23} \mathrm{C}_{6}$ 型の炭素位置にボロン原子が 6 12個の範团で 変化するとしている(17)。 $\tau$ 相の格子定数はボロン量の増加に つれて増加する。これは Stadelmaier らが指摘するように，ボ ロンが96個の金属原子炕よって構成された立方格子の稜に 1 個のボロン原子が，あるい性 2 個の原子が対として存在する ためである(7). 委た，Fig. 6 K示すよ5に，Chabon珄化学量 論組成の Ni 過剩側 $\mathrm{NiAl}$ と共存するもら一つのボライド $\pi$ 相 の存在を認めている。㐌の組成は $\mathrm{Ni}_{8} \mathrm{AlB}_{11}$ であり, 結晶構造 は単斜晶系 $\left(a=3.58, b=1.093, c=1.63 \mathrm{~nm}, \beta=112^{\circ}\right)$ であるこ とを認めている(17). 本実験では Ni 過剩側でのボライドの析出 量が少ないため， $\pi$ 相についての同定はできなかった。

\section{2. ボロン添加による破壊モードの変化}

ボロン添加 $\mathrm{NiAl}$ 合金の破面観察によると，ボロン添加量の 增加に伴い， $\mathrm{Ni}$ 過㮃側， $\mathrm{Al}$ 過剩側のいずれに打いても破壊毛 一ドは粒界破壊から粒内破壊へ变化している。この点は $\mathrm{Ni}_{3} \mathrm{Al}$ 合金と異なっている． $\mathrm{Ni}_{3} \mathrm{Al}$ はボロン添加により， Ni 過剩側 で驚異的な延性增加が起こるのに対して，Al過剩側では延性 の改善が認められていない(18)。これは $\mathrm{Al}$ 過剩側でボロンが粒 界に偏析しないためであるとの考えるあるが(4)，まだ確かなこ とは解っていない.Al 過剩側の NiAl で, ボロンは粒界に多 
量に偏析しているので，破㙥モードの変化が起こるのであろう. Table 2 拈よびFig. 6 によれば，破壊モードの变化は NiAl の ボロン固溶限に関係なく，Ni 過剰側ではわずかのボロン添加 により，破壊モードが変わっている．この点は George らの結 果と同じである．彼らは化学量論組成の NiAl K0.003 mass\% のボロンを添加すると，室温に批いて粒界破壊は完全に抑充ら れることを指摘している(3).

同様な現象は B2 構造の FeAl 合金でる報告されている。 Crimp と Vedula は $\mathrm{Fe}$ 過鄱側の FeAl のボロン添加材, 無添 加材の室温引張実験を行い，0.078 mass\%ボロンを添加すると 破罣モードは粒界破壊から粒内破壊に变わることを報告し た(19)。残念ながら， NiAl, FeAl では破壊モードは変わって も， $\mathrm{Ni}_{3} \mathrm{Al}$ の上らな驚異的な伸びの改善は見られないようであ $ろ^{(3)(19)}$ 。これは $\mathrm{Ni}_{3} \mathrm{Al}$ 火比較して NiAl では金属結合としての 要素が少なくなっているためであるう，化学量論組成り NiA1 に执いてボロンが粒界に存在することをGeorge らはオージェ 分析により明らかにしている(3)，ボロンを添加した $\mathrm{Al}$ 過剩側 $\mathrm{NiAl}$ の破面のオージェ分析を行うことが必要である。市た， 破面観察だけでなく，強さと鞄性を定量的に評価できる試験に より，ボロン添加の効果をより明確にする必要がある。

Co-Al-B 3 元状態図は Ni-A1-B のそれとよく似ている。すな わち, Co 過剩側 $\mathrm{CoAl} \beta$ 相怯ボライドと共存し, $\mathrm{Al}$ 過剩側で は $\mathrm{CoAl} \beta$ 相と単体のボロン(B) 相と共存している(17). 一方, $\mathrm{Ni}-\mathrm{Ga}-\mathrm{B}$ 呿よび Co-Ga-B 03 元状態図を見れば，両者の化学 量論組成の両側で NiGa 拉よび CoGa $\beta$ 相はボライドと共存し ている(20)(21)。CoAl, NiGa，括よび CoGak対するボロン添加 の挙動について NiAlのそれと同じかどうかを確諗することは これからの課題である。

\section{V. 結 論}

（1）ボロンは炭素と異なり，NiA1 $\beta$ 相に侵入型に固溶し，格 子定数の変化率は $0.31 \mathrm{~nm} / \mathrm{at} \%$ に達する.

(2) $\mathrm{NiAl} \beta$ 相のボロンの固溶度は $\mathrm{Ni}$ 過剩側で大きく，化学 量論組成に近づくにつれ減少する. $\mathrm{Al}$ 過剰側の NiAl $\beta$ 相にボ ロンはほとえど固溶しない。

(3) $\mathrm{Ni}$ 過剩側の $\mathrm{NiAl}(45 \mathrm{at} \% \mathrm{Al}) \boldsymbol{\beta}$ 相と平衡するボライドは $\mathrm{Cr}_{23} \mathrm{C}_{6}$ 型の $\mathrm{Ni}_{20} \mathrm{Al}_{3} \mathrm{~B}_{6} \tau$ 相であり，その組成は $\mathrm{Ni}_{60} \mathrm{Al}_{10} \mathrm{~B}_{30}$ であ る. 格子定数は $1.0542 \mathrm{~nm}$ であり，報告されている值とよく 一致する.

（4）以上の結果から，既往のデータを絵合して, Ni-Al-B 3 元状態図の NiA1 $\beta$ 相近傍の $1373 \mathrm{~K}$ 等温断面図を構成した。
（5）NiAl 《ボロンを添加すれば，破壊モードは粒界破壊か ら粒内破填へ变化する。破填モードが変化するボロン濃度は $\mathrm{Ni}$ 過剩側で 0.003 mass\%であるが， $\mathrm{Al}$ 過剩側では0.02 mass\%以上のボロン添加量が必要である.

終かりに，ボライドの電子線マイクロ・アナライザー分析で お世話になった明星大学高分解能分析電子顕微鏡センターの 清宮義博博士に感謝し李す.

\section{文献}

（1）譚毅，篠田哲守，三島良直，鈴木朝夫：日本金属学 会誌, $\mathbf{5 7}$ (1993), 98.

(2) Ternary Alloys, Vol. 3, Ed by G. Petzow and G. Effenberg, VCH. New York, (1988), p. 201.

(3) E. P. George and C. T. Liu: J. Mater. Res., 5 (1990), 754.

(4) A. DasGupta, L. C. Smedskjaer, D. G. Legnini and R. W. Siegel: Mater. Let., 3(1985), 457.

(5) J. H. Westbrook and D. L. Wood: J. Inst. Metals, $91(1962-63), 174$.

(6) H. Lux and L. Eberle: Chem. Ber., 94(1961), 1562.

( 7 ) H. H. Stadelmaier, R. A. Draughn and G. Hofer: Z. Metallkde., 54(1963), 640.

(8) E. Ganglberger, H. Nowotny and F. Benesovsky: Monatsh. Chem., 97(1966), 494.

(9) Yu. B. Kuzma and N. S. Bilonizhko: Inorg. Mater., 7(1971), 542. (Translated from Izv. Akad. Nauk SSSR, Neorg. Mater., 7(1971), 620).

(10) E. M. Schulson and D. R. Barker: Scripta Metall., 17(1983), 519.

(11) W. B. Pearson: Handbook of Lattice Spacings and Structure of Metals, Pergamon Press, London, (1958), p. 919, $921,984,985$.

（12）細田秀樹 : 未発表, 東京工業大学, 1992.

(13) J. C. Schuster and H. Nowotny: Monatsh. Chem., 113 (1982), 163.

(14) R. L. Fleischer: Technical Information Series, Class 1, 92CRD131, June (1992), GE Research \& Development Center.

(15) H. H. Stadelmaier and A. C. Fraker: Metallwissen. Tech., 16(1962), 212.

(16) H. H. Stadelmaier and T. S. Yun: Z. Metallkde. $\mathbf{5 3}(1962), 754$.

(17) N. F. Chabon and Yu. B. Kuz'ma: Inorg. Mater., 9 (1973), 1886 (Translated from Izv. Akad. Nauk SSSR, Neorg. Mater., 9(1973), 2136).

(18) C. T. Liu, C. L. White and J. A. Horton: Acta Metall., $33(1985), 213$.

(19) M. A. Crimp and K. Vedula: Mater. Sci. Eng., 78(1986), 193.

(20) H. H. Stadelmaier and M. L. Fiedler: Z. Metallkde., 60(1969), 447.

(21) M. L. Fiedler, H. H. Stadelmaier and E. B. Snipes: Z. Metallkde., 68(1977), 765 . 